\title{
Factors Associated with Post Traumatic Stress Disorder and Depression among Nepalese Combatants during Armed Insurgency
}

\author{
Rawal N1, Karki R², Shrestha DB³, Manandhar P1, Pathak N
}

1. Consultant Neuro-Psychiatrist, Department of Psychiatry, Shree Birendra Hospital (SBH), Chhauni 2. Resident (Former), Department of Community Medicine and Public Health, Maharajgunj Medical Campus, Kathmandu, Nepal 3. Intern, Shree Birendra Hospital (SBH), Chhauni 4. Neuro-Psychiatrist, Armed Police Force Hospital, Kathmandu

E-mail *Corresponding author: namrata_mahara@yahoo.com

\section{Abstract}

Introduction: Mental illness is major global public health problem affecting over 450 million people, most of whom live in developing countries. Nepal just overcame ten years long conflict situation. Post-traumatic stress disorder (PTSD) and depression is most prevalent in conflict inflicted areas as per most literatures. Much is not known about the psychological effects of the conflict situation, even after six years of peace process in Nepalese context.

Material And Method: This is a cross sectional descriptive study carried out to explore the prevalence of Posttraumatic stress disorder and Depression in Nepalese army combatants involved during the armed insurgency period and its relationship with different. It was conducted in two randomly selected battalions of tenth brigade in Kathmandu. The PTSD was assessed using Post traumatic stress disorder checklist - military version (PCL-M), depression was assessed using the Beck depression inventory (BDI) and degree of combat exposure was assessed using Combat exposure scale (CES). The quantitative assessment was done using appropriate methods and tools.

Results The degree of combat exposure showed $48.8 \%$ exposed to moderate and above degree of combat exposure. PTSD was found in $21.9 \%$ of the combats and $20.5 \%$ were found to have depression. Both PTSD and depression were found to be associated with degree of combat exposure. There was statistically significant association between degree of combat exposure and PTSD $(p=0.001,95 \%$ CI (1.567-6.303)) and depression $(p=0.011,95 \%$ CI (1.2094.830)).

Conclusion: PTSD and depression exists even six years after the peace process in Nepalese army and is related to the degree of combat exposure regardless of other attributes like age, sex, rank, marital status.

Keywords: Post-Traumatic Stress Disorder, Combat Exposure, Nepalese Army

\section{INTRODUCTION}

Globally, more than 450 million people suffer from mental disorders with large proportion from low- and middle-income countries with depression being the prominent one. ${ }^{1}$ Wars and conflicts are continuous process, having catastrophic effect on the health and wellbeing of nations and its citizens in both short term as well as in long term..$^{2}$ In 1980, one of the main consequence of traumatic experiences, Post traumatic stress disorder (PTSD) was recognized. ${ }^{3}$ Many factors, including deployment and combat, are known to increase the risk of psychological distress and psychiatric injury. ${ }^{4}$ The WHO projects, during armed conflicts around the globe, $10 \%$ of the people experiencing traumatic events will develop serious mental illness and another $10 \%$ will 
develop behavioral problems. ${ }^{5}$

Nepal just overcame a 10-year long conflict situation, 1996-2006, costing over 15,000 lives. It began as violent insurgency, continued through killings, torture, bombings, kidnappings, extortion against civilians, police, and public officials. Many of them were extra-judicially executed or 'disappeared' along with an unquantifiable number of combatants killed in battles in genuine encounters. ${ }^{6}$ Frequent intense involvement in combat operations increases the risk of developing PTSD and associated mental health problems. Poor diet, weather conditions, terrain, deficient accommodations with extensive time away from family serve as stressor.7,8

In Nepal, even with the history of armed insurgency for ten years no adequate explorations and studies is being done to describe the magnitude and nature of stress disorders present in relation to combat experience. This study will explore the magnitude of PTSD and Depression in Nepalese army six years after the peace process.

\section{MATERIAL AND METHOD}

This study is a cross sectional descriptive study carried out to explore the prevalence of PTSD in Nepalese army combatants involved during the armed insurgency period and its relationship with different attributes like age, sex, marital status, rank and degree of combat exposure. Male soldiers in service with minimum eight years duration of service with history of deployment and combat exposure were included. Those medically scrutinized and out of barracks during the study period were excluded. Study was conducted over period of six months starting from mid-July 2012.

Calculation of sample size was done by using Epi data for cross-sectional study. Based on literature review expected percent of prevalence of post-traumatic stress disorder was taken as $15 \%$. Confidence interval of $95 \%$ was taken.

The sample size was calculated as:

$$
\mathrm{n}=\frac{\mathrm{Z}^{2} \mathrm{a} / 2 \mathrm{P}(1-\mathrm{P})}{\mathrm{d}^{2}}
$$

$\mathrm{n}=$ minimal sample size

$\mathrm{Z}=$ the standard normal deviation set at 1.96 which corresponds to the $95 \%$ confidence level.

$\mathrm{P}=$ Prevalence of PTSD $=0.15(15 \%)$

$\mathrm{q}=(1-\mathrm{P})=(1-0.15)=0.85$ $\mathrm{d}=$ degree of precision or maximum allowable error $=5 \%(0.05)$

Non-response rate $=10 \%$

Total sample will be $=215$

The study was conducted in two battalions under the $10^{\text {th }}$ brigade chosen randomly. The $10^{\text {th }}$ brigade in Kathmandu valley was chosen purposively as all the five battalions under the $10^{\text {th }}$ brigade were deployed during the conflict period to different part of the country. The questionnaire was distributed in groups of 25 with a briefing to each group about the aim of study and direction to fill the questionnaire with the insurgency period and its effect on self during the last month in mind. Data collection for interpretation was done using post-traumatic stress disorder checklist-military version, Beck depression inventory and Combat exposure scale. 9,10

Before data collection, the contents of the questionnaire were thoroughly checked and pretested among the non-deployed army men working in Shree Birendra Hospital. The data collected was initially edited, coded, entered, checked and processed using Epi- Data. Once data entry was complete, it was then transferred to SPSS full version 19. Chi Square was used to describe the association between general characteristics, Post traumatic stress disorder and depression and its association with each other.

Formal permission was taken from thesis committee of Department of Community Medicine and Public Health, Institute of Medicine, Shree Birendra Hospital and Directorate General of Medical Services, Nepalese army and a request letter from the Nepalese army was given to each barracks from which the data was collected. The study was strictly voluntary participation. The participants were given full rights to withdraw from the study at any time or refuse to answer the question if they did not want to respond, without any obligation.

\section{RESULT}

Most $(182,84.7 \%)$ of the combatants were below 35 years of age, with most $(82.8 \%)$ completing education above class ten. Among all 90.2\% were married. 
Table 1: General Attributes of the Participants

\begin{tabular}{|c|c|c|}
\hline Characteristics & $\begin{array}{l}\text { Frequency } \\
(n=215)\end{array}$ & Percent \\
\hline \multicolumn{3}{|l|}{ Age } \\
\hline 20-25years & 9 & 4.2 \\
\hline 26-30years & 90 & 41.9 \\
\hline 31-35years & 83 & 38.6 \\
\hline 36-40years & 27 & 12.6 \\
\hline 41-45years & 6 & 2.8 \\
\hline \multicolumn{3}{|l|}{ Education } \\
\hline$<$ Class 10 & 37 & 17.2 \\
\hline$>$ Class 10 & 178 & 82.8 \\
\hline \multicolumn{3}{|l|}{ Marital Status } \\
\hline Married & 194 & 90.2 \\
\hline Unmarried & 21 & 9.8 \\
\hline \multicolumn{3}{|l|}{ Rank } \\
\hline Officers & 15 & 7 \\
\hline
\end{tabular}

The mean score on Post Traumatic Stress Disorder Checklist was $38.87 \pm 13.81$. The univariate analysis showed that among 215 respondents participating in the study $21.9 \%$ of the total participants met the criteria of PTSD. The mean score for BDI II was $6.72 \pm 7.481$ and the highest score of 35. Among the total participants $20.5 \%$ (44) combats met the criteria for depression while $79.5 \%$ (171) did not. Among total combats, $12.1 \%$ (26) had mild depression, and $7.9 \%$ (17) with moderate depression and $0.5 \%$ (1) had severe depression respectively. Majority of combats were exposed to light moderate to moderate degree of combat exposure with light moderate $35.8 \%$ and moderate $34.4 \%$ (Table 2.).

\section{Table 2: Categories of Combat Exposure Scale}

\begin{tabular}{|c|c|c|}
\hline Categories & Frequency & Percent \\
\hline Light & 33 & 15.3 \\
\hline Light moderate & 77 & 35.8 \\
\hline Moderate & 74 & 34.4 \\
\hline Moderate Heavy & 22 & 10.2 \\
\hline
\end{tabular}

The chi square test of association between PTSD and different attributes is shown (Table $3 \& 4$ ). There was statistically significant association between degree of combat exposure and PTSD $(p=0.001,95 \%$ CI (1.567-6.303)) however, no significant association between the attributes and outcome variables were seen $(p>0.05)$.

There was statistically significant association between degree of combat exposure and depression ( $\mathrm{p}=0.011,95 \%$ CI (1.209-4.830)).

Table 3: Relationship between Post traumatic stress disorder and other characteristics

\begin{tabular}{|c|c|c|c|}
\hline \multirow[t]{3}{*}{ Characteristics } & \multicolumn{2}{|l|}{ PTSD } & \multirow[t]{3}{*}{$\mathrm{p}$-value } \\
\hline & \multicolumn{2}{|l|}{ Yes } & \\
\hline & $\begin{array}{l}\text { Frequency } \\
(\%)\end{array}$ & $\begin{array}{l}\text { Frequency } \\
(\%)\end{array}$ & \\
\hline \multicolumn{3}{|l|}{ Age } & \multirow[t]{3}{*}{0.922} \\
\hline$<35$ years & $40(18.6)$ & $142(66)$ & \\
\hline >35years & $7(3.3)$ & $26(12.1)$ & \\
\hline \multicolumn{3}{|l|}{ Education } & \multirow[t]{3}{*}{0.690} \\
\hline Class 10 & $9(4.2)$ & $28(13)$ & \\
\hline$>$ Class 10 & $38(17.7)$ & $140(65.1)$ & \\
\hline \multicolumn{3}{|l|}{ Marital Status } & \multirow[t]{3}{*}{0.150} \\
\hline Married & $45(20.9)$ & $149(69.3)$ & \\
\hline Unmarried & $2(0.9)$ & $19(8.8)$ & \\
\hline \multicolumn{3}{|l|}{ Rank } & \multirow[t]{3}{*}{0.200} \\
\hline Officers & $1(0.5)$ & $14(6.5)$ & \\
\hline Non-officers & $46(21.4)$ & $154(71.6)$ & \\
\hline \multicolumn{3}{|l|}{ Combat } & \multirow[t]{3}{*}{0.001} \\
\hline Below & 14 & 96 & \\
\hline Moderate and & 33 & 72 & \\
\hline
\end{tabular}

\section{DISCUSSION:}

It has been known that not many studies have been done on the issue of mental health in Nepal, especially after the history of 10 years long armed insurgency. Though few studies have been conducted on general population of the conflict affected areas, this study was one of the first conducted in the Nepalese army combats deployed during the armed insurgency period. The purpose of the study was to find out the prevalence of post-traumatic stress disorder, depression and its relation with the degree of combat exposure to traumatic events and different attributes associated with them. 
Table 4: Relationship between Depression and other characteristics

\begin{tabular}{|c|c|c|c|}
\hline \multirow[t]{3}{*}{ Characteristics } & \multicolumn{2}{|c|}{ DEPRESSION } & \multirow{3}{*}{$\begin{array}{l}\mathrm{p}- \\
\text { value }\end{array}$} \\
\hline & \multicolumn{2}{|l|}{ Yes } & \\
\hline & $\begin{array}{l}\text { Frequency } \\
(\%)\end{array}$ & $\begin{array}{l}\text { Frequency } \\
(\%)\end{array}$ & \\
\hline \multicolumn{3}{|l|}{ Age } & \multirow[t]{3}{*}{0.78} \\
\hline$<35$ years & 41(19.1) & $141(65.6)$ & \\
\hline >35years & $3(1.4)$ & $30(14)$ & \\
\hline \multicolumn{3}{|l|}{ Education } & \multirow[t]{3}{*}{0.481} \\
\hline Class 10 & $6(2.8)$ & $31(14.4)$ & \\
\hline$>$ Class 10 & $38(17.7)$ & $140(65.1)$ & \\
\hline \multicolumn{3}{|l|}{ Marital Status } & \multirow[t]{3}{*}{0.060} \\
\hline Married & $43(20)$ & $151(70.2)$ & \\
\hline Unmarried & $1(0.5)$ & $20(9.3)$ & \\
\hline \multicolumn{3}{|l|}{ Rank } & \multirow[t]{3}{*}{ NA } \\
\hline Officers & $0(0)$ & $15(7)$ & \\
\hline Non-officers & $44(20.5)$ & $156(72.6)$ & \\
\hline \multicolumn{3}{|l|}{$\begin{array}{l}\text { Combat } \\
\text { exposure }\end{array}$} & \multirow[t]{3}{*}{0.011} \\
\hline $\begin{array}{l}\text { Below } \\
\text { moderate }\end{array}$ & $15(7)$ & $95(44.2)$ & \\
\hline $\begin{array}{l}\text { Moderate and } \\
\text { above }\end{array}$ & $29(13.5)$ & $76(35.3)$ & \\
\hline
\end{tabular}

Post-traumatic stress disorder was based on the validated standardized tool PCL-M with cut off score of $>50,47$ participants $(21.9 \%)$ met the criteria of the PTSD which in comparison to other studies conducted in different countries is consistent. In Persian Gulf War veterans within 5 days of return, reported the prevalence of PTSD to be $3-7 \%$ which later increased at follow up to $8-16 \%$ after $18-24$ months. Similarly, in US veterans, deployed to Operation Iraqi Freedom (OIF) and Operation Enduring Freedom (OEF), PTSD was present in $18.1 \%-19.9 \%$ of the returning OIF soldiers and $11.5 \%$ of the returning OEF soldiers. The prevalence of PTSD in Australian sample was $21 \%$ lifetime among Australian Defense Force Vietnam Veterans. ${ }^{11}$ The slight differences in the prevalence may be due to difference in demographics, military training and combat experiences.

Depression was assessed using a validated beck depression inventory tool where 44 participants
$(20.4 \%)$ met the criteria for depression with $12.1 \%$ falling under mild depression, $7.9 \%$ under moderate and $0.5 \%$ under severe depression. In studies conducted in general population in remote areas of Nepal among those involved during armed insurgency period showed 27.5\% met the threshold for depression. ${ }^{12}$ A similar study among general population of Jumla District showed $33.7 \%$ prevalence of depression. ${ }^{13}$ In Gulf war veterans, mental disorder and psychological symptoms were more prevalent in the deployed veterans $(18 \%) .{ }^{14}$ Many literatures have also shown that depression can occur alone or as co morbidity with PTSD. Our study also showed similar consistent results.

Among the different attributes, degree of combat exposure was found to be associated with PTSD and depression in our study. It is possible that other attributes were found not to be associated because of small sample size of this study. Other studies have sample size in thousands in compare to our study with sample size 215. In most studies the findings revealed the higher rates of PTSD among personnel who were younger, less educated and with lower rank. Exposure to traumatic event is a wellknown hazard of war and conflict situation and a precipitating factor of psychiatric morbidity depending upon individual vulnerability. Consistent with prior research traumatic stress and increased degree of combat exposure was associated with depression and PTSD. It is seen that both PTSD and depression are prevalent disorders. Since these findings are retrospective in nature, they may be biased like recall bias. Healthy worker effect is one form possible as only those combats present in the barracks were included. Those in service at the moment are almost by definition healthier than the general population.

The study can be used as a preliminary study to know the status of mental health. The results and recommendations can be helpful for the organization to identify and treat the combats with the disorder and to further plan for future to reduce the impact on the combats of the combat exposure. The study can be used as a stepping stone and further research can be done giving it continuity and knowing better and in detail about the mental impact of the insurgency period. 


\section{CONCLUSION:}

Post-traumatic stress disorder and depression due to armed insurgency exists in significant portion of the individuals exposed to war even 6 years after the peace process. This study shows that there was no significant association between the attributes like age, sex, education, rank and marital status. This study shows that main relationship between the PTSD and depression is with degree of exposure. This is a preliminary research so there is a need of similar but a larger scale study to confirm these results and to further analyze the impact of ten years long conflict period. Early identification and early intervention such as psychological debriefing and training modules for the whole army may be helpful.

\section{REFERENCES:}

1. Wikipedia. Mental Health. http://en.wikipedia.org/wiki/Mental_health.

2. Murthy RS, Lakshminarayana R. Mental health consequences of war: a brief review of research findings'. Official Journal of World Psychiatric association.2006;5(1):25-30.

3. Ikin JF, Sim MR, McKenzie DP, Horsley KW, Wilson EJ, Moore MR, Jelfs P, Harrex WK, Henderson S. Anxiety, post-traumatic stress disorder and depression in Korean War veterans 50 years after the war. Br J Psychiatry. 2007 Jun 1;190(6):475-83.

https://doi.org/10.1192/bjp.bp.106.025684 PMid:17541106

4. Iversen AC, van Staden $L$, Hughes JH, Browne T, Hull L, Hall J, Greenberg N, Rona RJ, Hotopf $M$, Wessely S, Fear NT. The prevalence of common mental disorders and PTSD in the UK military: using data from a clinical interviewbased study. BMC Psychiatry. 2009 Oct 30;9(1):68. https://doi.org/10.1186/1471-244X-968 PMid:19878538 PMCid:PMC2774683

5. World Health Organization. Mental health: strengthening our response. http://www.who.int/mediacentre/factsheets/fs220 len/ (accessed 2nd July 2012).

6. Wikipedia. Nepalese civil war. http://en.wikipedia.org/wiki/Nepalese_Civil_War

7. Litz BT. A Brief Primer on the Mental Health Impact of the Wars in Afghanistan and Iraq. http://www.ptsd.ne.gov/pdfs/impact-of-the-warsin-afghanistan-iraq.pdf (accessed 2nd October 2012)

8. Pols H, Oak S. War and Military Mental Health. Am J Psychiatry. December
2007:97:2132-42.

https://doi.org/10.2105/AJPH.2006.090910

9. Weathers, 1993. Post-traumatic Stress Disorder Checklist

(PCL). http://www.ptsd.va.gov/professional/pages/assess ments/ptsd-checklist.asp (accessed 15th June 2012).

10. Beck AT, Steer RA, Brown GK. Beck Depression Inventory - 2nd Edition (BDI-II). http://www.musc.edu/dfm/RCMAR/Beck.html (accessed 22 Nov 2012).

11. Richardson LK, Frueh BC, Acierno R. Prevalence estimates of combat-related post-traumatic stress disorder: critical review. Aust N Z J Psychiatry. 2010 Jan;44(1):4-19. https://doi.org/10.3109/00048670903393597 PMid:20073563 PMCid:PMC2891773

12. Luitel NP, Jordans MJ, Sapkota RP, Tol WA, Kohrt BA, Thapa SB, Komproe IH, Sharma B. Conflict and mental health: a cross-sectional epidemiological study in Nepal. Soc Psychiatry Psychiatr Epidemiol. 2013 Feb 1;48(2):183-93. https://doi.org/10.1007/s00127-012-0539-0 PMid:22777395

13. Kohrt BA, Speckman RA, Kunz RD, Baldwin JL, Upadhaya N, Acharya NR, Sharma VD, Nepal MK, Worthman CM. Culture in psychiatric epidemiology: using ethnography and multiple mediator models to assess the relationship of caste with depression and anxiety in Nepal. Ann Hum Biol. 2009 Jan 1;36(3):26180. https://doi.org/10.1080/03014460902839194 PMid:19381985 PMCid:PMC3907946

14. Toomey R, Kang HK, Karlinsky J, Baker DG, Vasterling JJ, Alpern R, Reda DJ, Henderson WG, Murphy FM, Eisen SA. Mental health of US Gulf War veterans 10 years after the war. $\mathrm{Br}$ J Psychiatry. 2007 May 1;190(5):385-93. https://doi.org/10.1192/bjp.bp.105.019539 PMid:17470952 